FENOMENA PEMAHAMAN DAN PENERAPAN HAKIKAT MAKNA KATA KEJAHATAN DAN PELANGGARAN DALAM PERKEMBANGAN HUKUM

Hamsir

$\mathrm{OO}$

IJTIHAD DAN URGENSINYA

Usman Jafar

$\longrightarrow 0$

PARTISIPASI POLITIK DALAM KONSEPSI TEORI PILIHAN RASIONAL JAMES S COLEMAN

Nila Sastrawati

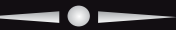

THAHARAH LAHIR DAN BATIN DALAM AL-QURAN

(Penafsiran terhadap Qs. Al-Muddatsir/74:4 dan Qs. Al-Maidah/5:6)

Ahmad Mujahid, Haeriyyah

$\longrightarrow \mathrm{O}$

STUDI KRITIS PERNIKAHAN BAWAH UMUR PERSPEKTIF UUP NO. 16 TAHUN 2019 DAN GENDER ANALISIS

Sippah Chotban

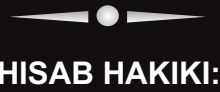

Metode IImiah Penentuan Awal Bulan Kamariyah

Alimuddin

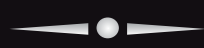

POLIGAMI DALAM SOROTAN

(Kajian Kitab-kitab Tafsir Modern/Kontemporer)

Halimah B

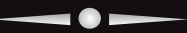

ADAT AMPIKALE:

Asuransi Ala Masyarakat Bugis di Kecamatan Pammana Kabupaten Wajo

Hadi Daeng Mapuna

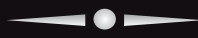

MEDIA SOSIAL DAN DAMPAKNYA TERHADAP PERCERAIAN

Sohrah

ה:i: HIMPUNAN ILMUWAN DAN SARJANA SYARIAH INDONESIA 


\section{$\underline{\text { Al-Risalah }}$}

Jurnal Ilmu Syariah dan Hukum

\section{DAFTAR ISI}

FENOMENA PEMAHAMAN DAN PENERAPAN HAKIKAT MAKNA KATA

KEJAHATAN DAN PELANGGARAN DALAM PERKEMBANGAN HUKUM

Hamsir

IJTIHAD DAN URGENSINYA

Usman Jafar

PARTISIPASI POLITIK DALAM KONSEPSI TEORI PILIHAN

RASIONAL JAMES S COLEMAN

Nila Sastrawati

THAHARAH LAHIR DAN BATIN DALAM AL-QURAN

(Penafsiran terhadap Qs. Al-Muddatsir/74:4 dan Qs. Al-Maidah/5:6)

Ahmad Mujahid, Haeriyyah

STUDI KRITIS PERNIKAHAN BAWAH UMUR PERSPEKTIF UUP NO. 16

TAHUN 2019 DAN GENDER ANALISIS

Sippah Chotban

HISAB HAKIKI: Metode Ilmiah Penentuan Awal Bulan Kamariyah

Alimuddin

POLIGAMI DALAM SOROTAN (Kajian Kitab-kitab Tafsir

Modern/Kontemporer)

Halimah B 
PERILAKU SEKSUAL TRANSGENDER

254-275

(Studi Komparatif Hak Asasi Manusia Antara Perspektif The Universal

Declaration of Human Right dan The Cairo Declaration of Human Right)

Adriana Mustafa

ADAT AMPIKALE: Asuransi Ala Masyarakat Bugis di Kecamatan Pammana

Kabupaten Wajo

276-285

Hadi Daeng Mapuna

MEDIA SOSIAL DAN DAMPAKNYA TERHADAP PERCERAIAN

286-296

Sohrah 


\title{
THAHARAH LAHIR DAN BATIN DALAM AL-QURAN (Penafsiran terhadap Qs. Al-Muddatsir/74:4 dan Qs. Al-Maidah/5:6)
}

\author{
Ahmad Mujahid \\ UIN Alauddin Makassar DPK UNHAS
}

Haeriyyah

Universitas Hasanuddin

\section{Abstract}

One of the fundamental problems of the religious diversity of most Muslims today is that they are religiously textual or infantile, minus the meaning of irfani. They are religious limited to rituals and lack of inner meaning. As a result they stop in religion at the means and do not arrive at the religious goals. For example, they only feel that they are sufficient in sharia ablution or prayer but minus the inner meaning or essence. As a result, the ablution and prayer that they perform does not lead to the essence of religion, the essence of ablution and the essence of prayer. This paper discusses how the inner or irfani meanings of the essence of thaharah and the nature of wudoo, without ignoring the core meanings (syar'iyah and bayani).

Keywords: Essence of Religion, Meaning of Thaharah, Al-Quran

\section{A. PENDAHULUAN}

Thaharah merupakan problem paling utama, pertama dan fundamental dalam beragama. Thaharah adalah landasan utama dalam beribadah. Oleh karena itu, sangat beralasan, kalau kitab-kitab fiqhi dan kitab-kitab hadis sering kali dimulai dengan bab pembahasan tentang thaharah. Hanya saja yang problematik adalah pembahasan tentang thaharah lebih ditekankan pada aspek lahiriahnya dan minus makna batin dan atau makna hakekatnya. Akibatnya kebanyakan umat Islam menjalankan syariat agama sebatas syariat lahiriah tanpa makna esensial. Kebanyakan umat Islam memahami agama hanya secara bayani minus irfani. Akhirnya mereka merasa cukup pada pelaksanaan syariat agama meskipun pelaksanaan syariat agama tersebut belum dan atau tidak membentuk karaktek akhlak kemuliaan. Contohnya dalam memahami sabda Rasulullah Saw. tentang shalat yakni "shalluu kaam raitumuuni ushalliy," 'shalatlah kalian sebagaimana kalian melihat saya shalat.' Hadis ini cenderung hanya dipahami secara lahir dan atau tekstual bayani, minus makan batin dan atau irfani.

Sangat sedikit umat Islam yang bertanya tentang shalat Rasulullah saw secara batin. Misalnya bagaimana suasana batin Rasulullah saw ketikan ia shalat, ketika takbir, ketika ia membaca ummul kitab, ketika ia ruku dan sujud serta tahiyat. Demikian pula dalam syariat wudhu. Pembahasannya lebih bersifat lahiriah tekstual dan minus batin dan atau irfaniah. Yakni bagaimana hati dan batin Rasulullah ketika berwudhu? Kalau saja Imam Ali km. Imam Hasan-Husain, Fatimah az-Zahra (purti kesayangan Rasulullah), apabila 
berwudhu, muka mereka kelihatan pucat ketakutan. Dan ketika mereka ditanya, mengapa wajah kalian pucat ketakutan ketika berwudhu. Mereka menjawab; tahukah kalian kepada siapa yang akan menghadap pasca berwudhu? Jawaban mereka sungguh menggambarkan suasana batin mereka ketika berwudhu. Mereka tidak hanya berwudhu secara lahir tetapi plus batin. Yakni berwudhu dengan penuh kesadaran batiniah dan atau irfaniah. Dalam konteks makna yang demikian ini, tulisan ini hadir. Yakni membahas tentang thaharan secara lahir dan batin. Secara bayani dan sekaligus irfani.

\section{B. TERMA THAHARAH SECARA BAHASA DAN PENGGUNAANYA DALAM ALQURAN}

Terma thaharah dari sudut etimologis menunjuk makna pokok bersih dan atau hilangnya kotoran. Dari sudut etimologis menunjuk beberapa makna yakni suci bersih lawan dari najis, menjauhkan, mensucikan dan membersihkan, membasmi hama dan membersihkan kuman, membasuh, memandikan, mencuci, bersih dari kotoran/najis, mandi, khitan atau sunat, suci hati, jujur dan lain-lain (al-Munawwir/951).

Terma "thaharah" dalam berbagai bentuk derivasi ditemukan penggunaannya dalam al-Quran sebanyak 31 kali. Yakni sekali dalam bentuk kata kerja yang menunjuk waktu lampau (fi'il al-madhi), seperti dalamQS. Ali Imran/3: 42; dalam bentuk kata kerja yang menunjuk makna sekarang dan akan datang (fi'il al-mudhariy), ditemukan penggunaannya sebanyak 10 kali, seperti dalam QS. al-Maidah/5: 6 dan 41; dalam bentuk kata perintah (fi'il alamr) ditemukan penggunaannya sebanyak 4 kali yakni dalam QS. al-Hajj/22: 26, QS. al-Maidah/5: 6; QS. al-Baqarah/ 2: 125; dalam bentuk kata "thahuur ditemukan 2 kali, seperti dalam QS. al-Furqan/25: 48; dalam bentuk kata tathhiir sebanyak sekali yakni QS. al-Ahzab/33: 33; dalam bentuk kata athhar sebanyak 4 kali, antara lain dalam QS. Hud/11: 78; dalam bentuk kata muthahhir dan atau muthahhirah digunakan sebanyak 6 kali, antara lain dalam QS. Ali Imran/3: 15; dalam bentuk kata muthahhirun dan kata muthahhirin, masing-masing digunakan sebanyak sekali yakni QS. al-Waqiyah/56: 79 dan QS. al-Taubah/9: 108. sedang dalam bentuk kata mutathahhiriin juga sebanyak sekali yakni dalam QS. al-Baqarah/2: 222. (mu'jam Mufahras li al-Fadh alQuran/428-429).

Al-Ashfahany menjelaskan bahwa kata al-thaharah yang berarti suci menunjuk dua hal yakni pertama suci secara jasmani dan kedua adalah suci rohani. Lebih lanjut ia menegaskan bahwa ayat-ayat al-Quran yang menggunakan term thahaarah ini menunjuk kepada kedua jenis kesucian tersebut. (mufradat fi gharib al-Quran/II, 596). Al-Husaini Muhammad aldamaaghani menulis dalam kitabnya beberap makna dari penggunaan terma yang berakar pada huruf tha, kha dan ra dalam al-Quran yakni; pertama, mandi seperti dalam QS. al-Baqarah/2: 222; kedua, bermakna istinja seperti dalam QS. al-Taubah/9: 108; ketiga, suci dari semua najis, seperti dalam QS. alAnfal/8: 11; keempat bermakna suci dari dosa liwat, seperti dalam QS. alA'raf/7: 82; kelima bermakna suci dari darah haid seperti dalam QS. al-Nisa' /4: 
57; keenam bermakna suci dari syirik seperti dalam QS. Abasa/80: 14; ketujuh bermakna suci dari keraguan, seperti dalam QS. al-Baqarah/2: 232; kesembilan bermakna suci dari dosa dan fakhisyah, seperti dalam QS. al-Ahzab/33: 33; dan kesepuluh adalah halal seperti dalam QS. Hud/11: 78. (Kamus al-Quran/298300).

Berdasarkan penggunaan terma thaharah dalam Alquran dan berbagai maknanya dapat disimpulkan bahwa konsepsi thaharah mencakup kesucian lahir dan kesucian batin. Kesucian lahir mencakup kesucian dari kotoran, najis, hadas. Sedang kesucian batin mencakup kesucian dari dosa dan kemaksiatan, kesucian dari sifat-sifat buruk serta kesucian hati dari syirik. Berikut uraiannya lebih lanjut.

\section{KONSEP KESUCIAN LAHIR DAN BATIN PENAFSIRAN TERHADAP QS. AL-MUDATSIR/74: 4 DAN QS. AL-MAIDAH/5: 6}

Untuk memahami pembahasan bagian kesucian lahir dan batin dalam Alquran, maka akan ditelusuran ayat-ayat yang berakar pada huruf "tha, ha dan ra." Seperti QS. Al-Mudatsir/74:4 dan QS. al-Maidah/5: 6. Berikut urainnya lebih lanjut.

1. QS. Al-Mudatsir/74/04:4:

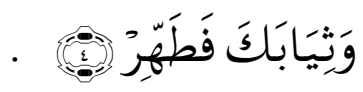

Kandungan ayat $4 \mathrm{di}$ atas adalah bagian dari pengajaran dan pendidikan Allah terhadap Rasulullah Saw. Yakni ia diperintahkan oleh Allah untuk mengsucikan pakaiannya. Kesucian pakaian dibutuhkan oleh seorang pemberi peringatan. Lalu apa yang dimaksud dengan pakaian dan atau kesucian pakain dalam konteks ayat 4 surah al-mudhastir tersebut?

Kata tsiyaab adalah bentuk jamak dari kata tsaub. Ibnu Faris menulis bahwa makna pokok kata "tsiyab" yang berakar pada huruf "tsa, wau dan ba," adalah kembali atau al-'aud dan atau al-rujuu'. (Ibnu Faris/I: h. 393). AlRaghib al-Ashfahaniy dalam kitabnya "al-Mufradat fi Ghariib Alquran" menjelaskan bahwa makna asal dari kata tsaub adalah kembalinya sesuatu kepada asalnya atau kondisi semula dan atau yang telah ditentukan untuknya. Seperti perkataan orang Arab yakni " tsaaba fulaan ila dhaarihi," yang berarti fulan kembali ke rumahnya. Juga pada kalimat "tsaaba ilayya nafsiy" yang berarti kesadaranku kembali. Adapun penggunaan kata tsaub dalam makna baju dalam hubungannya dengan makna asal dari kata tsaub adalah kembalinya pintalan pada kondisi semula yang telah ditentukan untuknya. Kata tsuab juga diartikan dengan makna pahala dan atau ganjaran. Oleh karena ganjaran dan atau balasan adalah sesuatu yang kembali kepada manusia atas perbuatannya sebagai balasan. Lebih lanjut al-Ashfahaniy mengatakan bahwa penggunaan kata tsiyab pada ayat 4 surah al-Mudtatsir menunjuk makna pakaian dan juga menunjuk makna jiwa sebagai makna kinayah. (al-mufradat fi gharib/h. 499-350). 
Berdasarkan keterangan makna dari terma tsiyab yang dikemukan dari sudut kebahasaan di atas, maka dapat dipahami bahwa terma tsiyaab pada ayat 4 surah ke 74 tersebut menunjuk dua makna yakni pertama makna lahir yaitu pakaian dan kedua makna batin yaitu jiwa. Adapun terma "fathahhir" merupakan kata perintah yang bermakna sucikanlah. Kata yang berakar pada huruf "tha, ha dan ra:," juga menunjuk makna lahiriah dan batiniah, seperti telah dikemukakan di atas. Dengan demikian, dapat ditegaskan bahwa penggabungan terma tsiyab dengan terma thahhir dalam ayat 4 surah ke 74 mencakup makna lahiriah atau hakiki dan makna batiniah atau kiayasi. Untuk memperdalam konsep kesucian dalam ayat 4 surah al-Mudatsir, lebih lanjut akan dikemukakan pandangan beberapa ahli tafsir, baik yang klasik maupun yang modern, sebagai berikut.

Menurut Naashir Makaarim al-Syiiraazi dalam tafsirnya ia menulis bahwa makna dari terma al-tsaub adalah makna kinayah yakni makna yang menunjuk kepada perbuatan manusia. Oleh karena perbuatan manusia itu menempati dan atau menggambarkan pakaiannya. Bentuk lahirnya menjelaskan batinnya. Pendapat lain memaknainya dengan makna hati dan atau roh. Yakni sucikan hatimu dan rohmu dari segala kotoran. Pendapat lain, mengartikan terma tsiyaab dengan makna pakaian. Diartikan demikian karena kebersihan pakaian menandakan baiknya pendidikan dan peradaban, khususnya pada masa jahiliyah. Pada masa ini, sangat sedikit orang yang menjauhi najis atau kotoran dan kebanyakan pakaian orang di masa jahiliyah tersebut, pakaiannya kotor. Ada lagi yang mengartikan makna tsiyaab dengan makna pasangan atau azwaaj. Pendapat ini didasarkan pada Qs. al-Baqarah/2: 187 (al-Syiraazi. AlAmtsal fi Tafsiir Kitab Allah al-Munazzal. 2005. XIX. h. 116).

Wahbah Zuhaili, ketika menafsirkan klausa "wa tsiyaabaka fathahhir," ia memaknainya dengan makna bersihkan dan atau sucikanlah pakaianmu dan jagalah dari najis.... Lebih lanjut ia juga memaknainya dengan makna bersihkanlah dirimu dari perbuatan-perbuatan dan atau akhlak-akhlak tercela. Selanjutnya ia mengemukakan pernyataan Qathada yang memaknai klausa tersebut dengan makna sucikanlah dari maksiat dan dosa-dosa. Menurut Wahba, orang Arab menyatakan orang yang berbuat dosa, tidak menetapi janji Allah dengan gelaran orang yang pakaiannya kotor. Sebaliknya orang yang berbuat kebajikan dan menjaga dirinya dari keburukan dan dosa dengan gelaran orang yang pakaiannya suci. Akhirnya Wahbah menegaskan bahwa kedua makna yang telah dikemukakan merupakan sebuah kebenaran. Sungguh kesucian indrawi berbarengan dengan kesucian maknawi. Artinya bersih dan jauh dari dosa maksiat. Sebaliknya adanya kotoran menunjukkan banyaknya dosa dan maksiat. (Wahbah. Tafsir al-Muniir. XV. h. 225).

Muhammad Quraish Shihab menjelaskan bahwa terma tsyiyab selain menunjuk makna pakaian juga dapat menunjuk makna kiasan, seperti ditemukan dalam kamus kebahasaan. Ada delapan makna kiasan dari kata tsiyab yakni hati, jiwa, usaha, badan, budi pekerti, keluarga, istri. Sedang makna pakaian adalah makna hakiki dari terma tsiyab (Quriash Shihab. Tafsir 
Al-Quran al-Karim: Tafsir Surah-surah Pendek Berdasarkan Urutan Turunnya. 1997. H. 224).

Untuk memahami lebih dalam konsep kesucian lahir dan batin, maka akan dikemukakan pembahasan ayat yang relevan dengan ibadah bersuci, yakni berwudhu. Seperti ditunjuk dalam QS. al-Maidah/5: 6:

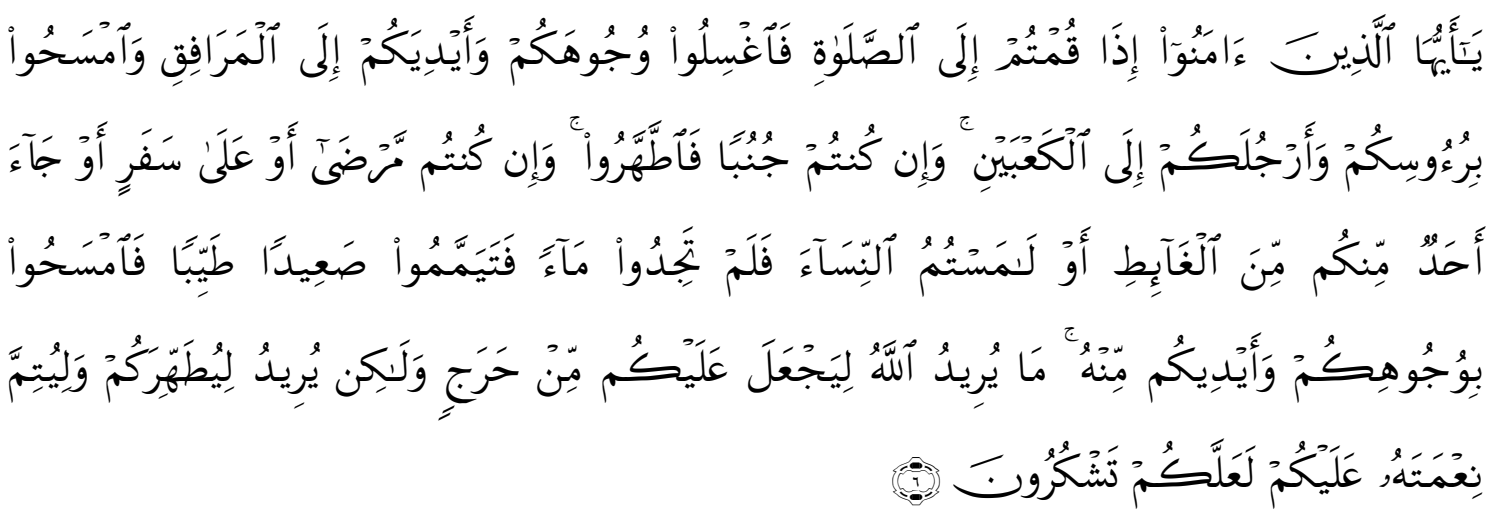

Terjemah:

"Hai orang-orang yang beriman, apabila kamu hendak mengerjakan shalat, Maka basuhlah mukamu dan tanganmu sampai dengan siku, dan sapulah kepalamu dan (basuh) kakimu sampai dengan kedua mata kaki, dan jika kamu junub Maka mandilah, dan jika kamu sakit atau dalam perjalanan atau kembali dari tempat buang air (kakus) atau menyentuh perempuan, lalu kamu tidak memperoleh air, maka bertayammumlah dengan tanah yang baik (bersih); sapulah mukamu dan tanganmu dengan tanah itu. Allah tidak hendak menyulitkan kamu, tetapi Dia hendak membersihkan kamu dan menyempurnakan nikmat-Nya bagimu, supaya kamu bersyukur.

Kandungan ayat 6 surah ke 5 di atas merupakan dalil syariat berwudhu, mandi junub dan tayammum. Ketiga ibadah syariat ini merupakan ibadahiabdah yang relevan dengan pensucian baik dalam makna pensucian lahir maupun pensucian batin. Uraian lebih lanjut, akan difokuskan pada ibadah wudhu dalam perspektif lahir dan batin. Namun sebelumnya akan dikemukakan beberapa keterangan ahli tafsir terkait dengan kandungan ayat 6 surah ke 5 di atas.

Kandungan ayat 6 dalam surah al-Maidah, merupakan tuntunan bagi seorang mukmin, yakni apabila ia hendak menegakkan shalat, sementara pada saat itu, ia dalam keadaan berhadas kecil dan atau berhadas besar, maka hendaknya ia berwudhu dan atau mandi. Selanjutnya ayat tersebut mengemukakan tata cara berwudhu. Yakni membasuh muka dan tangan hingga siku. Kemudian menyapu kepala yakni seluruhnya dan atau sedikit atau sebagian kepala. Selanjutnya membasuh kedua kaki hingga mata kaki. Kandungan ayat 6 tersebut juga menuntun seorang mukmin yang sedang junub dan atau mukminat sedang haid dan nifas, yang menjadi penghalang untuk menegakkan shalat, maka hendaknya ia mandi mensucikan diri. Lebih lanjut ayat 6 juga mengemukakan tata cara bersuci, -baik dari hadas kecil dan atau hadas besar-, apabila tidak menemukan air. Tata cara bersuci yang dimaksud adalah tayammum dengan menggunakan debu yang suci. Caranya 
adalah dengan menyapu muka dan tangan dengan debu yang baik dan atau suci. Tayammum merupakan tata cara bersuci yang menggantikan wudhu dan mandi bagi seorang mukmin yang lagi sakit, di mana penyakitnya dikhawatirkan bertambah parah apabila terkena air, dan atau dapat menundah kesembuhannya jika terkena air. Tayammum juga dapat digunakan sebagai tata cara bersci bagi seorang mukmin dan atau mukminat, yang sedang dalam perjalanan atau musafir dalam jarak tertentu dan ia tidak menemukan air. Demikian pula seorang mukmin-mukminat yang telah buang hajat dan atau telah berhubungan suami istri, sementara tidak menemukan air, dibenarkan bersuci dengan cara tayammum. Selanjutnya klausa penutup ayat 6 surah alMaidah menegaskan bahwa syariat bersuci dengan cara berwudhu, mandi dan atau tayammum merupakan penyempurnaan nikmat Allah yang mesti disyukuri dan juga merupakan cara Allah mensucikan hambaNya. Relasionalisasi klausa penutup ayat 6 surah al-Maidah dengan kandungan klausa-klausa sebelumnya, dapat dipahami dengan tegas bahwa berwudhu, mandi dan atau atau tayammum merupakan bentuk-bentuk ibadah yang bertujuan pensucian diri, baik secara lahir dan atau secara batin. Seperti akan diuraikan lebih lanjut. Namun sebelumnya terlebih dahulu dikemukakan keterangan ahli tafsir tentang kandungan ayat 6 surah al-Maidah di atas.

Kebanyakan ahli tafsir dalam mengomentari ayat 6 surah al-Maidah di atas dengan makna bersuci secara lahiriah saja. Seperti keterangan yang dikemukakan oleh Muhammad Ali ash-Shabuniy dalam tafsirnya (Muhammad Ali Ash Shabuuniy, Shafwatut Tafaasir/II: 15-16). Uraian yang lebih luas dikemukakan oleh Quraish shihab, namun uraiannya juga bersifat lahiriahsyar'iah (Tafsir al-Misbah/III: 33-37). Penjelasan lebih khusus yang bersifat lahiriah-fiqhiyah dikemukakan oleh Wahbah Zuhaili (Tafsir al-Muniir/III: 431447), demikian pula al-Qurthubi dalam tafsirnya. Lalu apa dan bagaimana makna batin dari berwudhu sebagai gerakan pensucian? Pertanyaann yang senada adalah mengapa shalat mesti dimulai dengan wudhu sebagai gerakan pensucian? Hal lain yang menarik dicermati lebih mendalam dari syariat wudhu dalam kaitannya dengan makna batinnya, yakni bahwa yang menjadi anggota wudhu adalah anggota tubuh yang sering melakukan dosa dan kemaksiatan. Mengapa bukan dubur dan kemaluan yang menjadi anggota wudhu? Padahal dari keduanya keluar najis yakni air seni dan tinja. Keluarnya kedua najis tersebut menyebab seseorang berhadas dan terhalang menegakkan shalat sebelum bersuci dengan cara wudhu, mandi dan atau tayammum. Berikut uraiannya.

Menurut penulis, mandi, tayammum dan khususnya wudhu merupakan ibadah pensucian yang subtansi maknanya lebih menekankan pada makna batin namun tidak mengabaikan makna lahir. Hal dapat dibuktikan dari hadishadis yang terkait dengan wudhu. Dalam hadis-hadis tersebut dipahami bahwa setiap anggota wudhu yang terbasuh, maka dosa-dosa kecil yang telah dilakukan oleh anggota-anggota wudhu tersebut akan jatuh bersamaan dengan jatuh air yang digunakan membasuh. Bahkan terdapat hadis yang mempermisalkan bahwa berwudhu sebanyak lima kali dalam sehari 
diperumpamakan dengan mandi sebanyak lima kali dalam sehari, maka dijamin tidak ada kotoran yang melekatkan di badan. Hadis ini meliputi makna lahir dan makna batin. Yakni kotoran lahir seperti daki dan kotoran batin yakni gugurnya dosa-dosa kecil. untuk dapat memahami lebih lanjut makna-makna batin dari syariat wudhu, penulis mengemukakan pandangan sufistik dan atau irfani Ibnu 'Arabiy dalam kitabnya "al-futuhaat al-Makkiyyah," yang bermakna Pengungkapan-Pengungkapan di Makkah. Berikut uraiannya.

Terkait dengan niat sebagai salah satu syarat thaharah wudhu. Menurut Ibnu Arabiy, secara batin hukumnya adalah sangat wajib. Dikatakan demikian karena niat memang merupakan wilayah batin dan atau pekerjaan hati. dalam konteks makna batin ini, para ulama tidak berbeda pendapat. Namun niat dalam makna lahir, terdapat perbedaan pendapat para ulama. Eksistensi niat dalam berwudhu diisyaratkan oleh klausa awal dalam ayat 6 surah al-Maidah yakni klausa "idza kuntum ila al-shalaat. Demikian keterangan Quraish Shihab (Tafsir al-Misbah/III; h. 33).

Adapun membasuh tangan sampai penggelangan tangan, secara lahiriah ulama berbeda pendapat. Sebagian ulama memandubkannya atau mensunnahkan. Sebagian lagi mewajibkannya yakni bagi orang-orang yang baru bangun tidur. Mereka diwajibkan membasuh tangannya sebelum memasukkannya ke dalam bejana wudhu. Dari sudut makna batin, membasuh tangan sebelum memasukkannya ke dalam bejana hukumnya wajib. Makna batin yang dimaksud adalah pensucian tangan dari segala apa yang dilarang oleh syariat, seperti mencuri, merampok, berbuat aniaya. Makna lainnya adalah membebaskan tangan dari benda-benda dunia meskipun dibolehkan. Yakni hidup dalam kesederhaan (zuhud). Dengan tujuan agar memperoleh dari sisi Allah yang lebih baik. Semua yang ditinggalkan dari dunia akan memperoleh ganti di sisi Allah yang lebih baik. Makna batin yang lain adalah meninggalkan yang subhat. Makna batin dari membasuh tangan yang tak kalah pentingnya dikemukakan adalah melepaskan diri dari kebodohan dan kelalaian. Makna kebodohan dipahami dari tidur malam dan makna kelalaian dipahami dari tidur siang. Tidur malam dan atau tidur siang, di mana tangan tidak diketahui ke mana ia menempel merupakan alasan utama mengapa diperintahkan tangan dicuci atau dibasuh sebelum dimasukkan ke dalam bejana. Lebih lanjut, Ibnu Arabiy mengatakan bahwa seseorang ketika membasuh dan atau mencuci tangan ketika berwudhu, hendaknya ia mengikrarkan dalam hatinya bahwa ia sedang berjalan menuju Allah.

Makna batin dari berkumur-kumur dan memasukkan air ke hidung atau istinsyaq. Meskipun secara syariat atau makna lahir, berkumur-kumur dan istinsyaq adalah hukumnya sunnah, namun dari sudut makna batin hukumnya wajib. Makna batin yang dimaksud Ibnu Arabiy dari berkumur-kumur adalah hendaknya membasahi lidah dengan zikir kepada Allah dan membebaskannya dari perkataan dusta dan atau kebohongan serta ucapan-ucapan makian, perkataan kotor dan ujaran-ujaran kebencian (QS. al-Nisa/4: 148). Oleh karena itu, menurut Ibnu Arabiy, dalam berkumur-kumur diwajibkan mengucapkan kalimat tauhid yakni "laa ilaha illa Allah." Tujuannya adalah agar lidahmu 
terbebas dari kesyirikan dan atau tenggelam dalam ketauhidan. Dengan begitu lidahmu terbebas dari segala bentuk ucapan dosa dan maksiat serta yang ucapan-ucapan sia-sia.

Sedang makna batin dari istinsyaq atau menghirup air ke hidung kemudian menghemburkannya adalah mencuci kesombongan dan kepongahan. Menurut Ibnu Arabiy, hidung dalam tradisi orang Arab adalah simbol kepongahan dan atau kesombongan. Orang Arab, apabila menghinakan dan atau mencomooh orang lain sering berkata "alaa raghmin anfik," yakni semoga Allah memaksa hidungnya dalam soal ini. Kata raghm juga bermakna debu. Dan debu mengandung makna kehinaan. Hidung dan debu didekatkan. Dengan demikian, makna batin dari istinsyaq adalah Allah menggugurkan dan atau menurunkan kepongahan, keangkuhan dan kesombonganmu ke tarap kehinaan dan kerendahan. Lebih lanjut Ibnu Arabiy berkata bahwa kesombongan hanya dapat dihilangkan dan dibersihkan dari diri seseorang dengan hukum ubudiah. Yakni menerapkan dan menghidupkan hukumhukum ubudiah dalam diri. Air yang dihirup ke hidung bermakna pengetahuan penghambaan atau ubudiyahmu. Lalu hembuskan air pengetahuan kehambaanmu keluar dari hidungmu, dengan demikian engkau telah membebaskan dirimu dari kepongahan dan kesombongan

Adapun membasuh muka sebagai salah satu anggota wudhu, para ulama sepakat akan kefadhuannya. Namun mereka secara lahir berbeda terkait batasan muka atau wajah. Kata wajah yakni muka merupakan totalitas diri seorang manusia. lewat wajahnya seseorang dapat dikenal. Misalnya jika ia berjalan dengan wajah terbuka meskipun seluruh anggota tubuhnya yang lain tertutup, maka ia tetap akan dikenal. Sebaliknya jika seluruh anggota tubuhnya terbuka, namun muka atau wajahnya tertutup, pasti ia tidak dapat dikenal. Ibnu Arabi mengemukakan bahwa makna batin dari mencuci muka dalam berwudhu adalah mawas diri dan haya' atau malu dihadapan Allah secara mutlak. Artinya ia tidak melewati batas ketetapan Allah. Yakni hendaknya seseorang mengawasi totalitas dirinya, mengawasi seluruh perbuatan yang dilakukannya dan atau perbuatan yang ditinggalkan, baik dari sisi lahir dan atau batin. Selain itu, seseorang mesti malu dihadapan Allah meninggalkan perintah-perintahNya dan mesti malu kepada Allah dalam melaksanakan laranganNya. Misalnya ia mesti mawar diri menggunakan mata atau penglihatannya dalam melihat sesuatu, dan mesti malu menggunakan mata atau penglihatannya melihat yang tidak diridhai Allah. Dalam konteks makna inilah Allah memerintahkan kepada mukmin laki-laki dan atau mukmin perempuan agar menundukkan pandangannya, seperti ditegaskan dalam QS. an-Nuur/24; 30-31. Ibnu Arabiy menegaskan bahwa menundukkan pandangan merupakan bagian dari pada malu dan mawas diri.

Selanjutnya anggota wudhu lainnya adalah membasuh tangan hingga siku. Para ulama pun sepakat kefardhuan membasuh tangan dalam berwudhu. Namun mereka berbeda pendapat dapat batasan tangan. Yakni apakah termasuk siku dan atau hanya batas siku. Ibnu Arabiy mengatakan bahwa membasuh tangan dalam makna batin adalah membasuh kedua tangan dengan 
kedermawanan, kebajikan, pemenuhan amanah, memberi manfaat dan memuliakan orang lain.

Adapun makna batin dari mengusab kepala, dapat dipahami dari istilah ra's yang berarti kepala. Ra's dinamai kepala karena ia adalah yang tertinggi kedudukannya pada diri atau tubuh manusia. Kepala adalah bagian teratas dari tubuh manusia. Seluruh bagian tubuh lainnya berada di bawah kepala. Kepala adalah pemimpin seluruh anggota tubuh manusia. kepala merupakan bagian termulia dan tertinggi manusia. kepala adalah bagian di mana otak manusia ditempatkan. Dan otak manusia merupakan pusat dari seluruh perintah terhadap anggota tubuh lainnya. Menurut Ibnu Arabiy, kepada adalah bagian yang terdekat dengan Tuhan dalam aspek ketinggian. Makna ini dipahami dari kandungan QS. al-Nahl/16: 50 dan al-An'am/6: 18. Pengusapan terhadap kepala dalam wudhu menunjuk makna penundukan wilayah ketinggian pada manusia kepada yang Maha Tinggi. Yakni dengan menghambakan diri kepada yang Maha Agung dan mengangkat kesombongan dan keangguhan dalam diri. Penghambaan kepada Allah yang Maha tinggi dengan penuh perendahan diri merupakan wujud esensial dari ubudiyah seorang hamba. Inilah bentuk hubungan sejati dengan sang Maha Suci dan merupakan pencapai dari sebuah gerakan pensucian atau thaharah. Selain pengusapan terhadap kepala, juga terdapat pengusapan terhadap telinga. Makna batin terhadap pengusapan terhadap telinga dengan air yang baru adalah mendengarkan ucapan-ucapan yang baik, kemudian mengikutinya. Demikian keterangan Ibnu Arabiy.

Anggota tubuh terakhir yang wajib disapu dalam berwudhu adalah kaki. Makna batin dari pensucian kedua kaki adalah dengan memperbanyak melangkah ke masjid dan berlari menuju keridhaan Allah dalam kesyahidan. Pada saat yang bersamaan mencegah kaki melangkah menuju tempat kemaksiatan dan atau berlari ke sana kemari menyebarkan fitnah. Inilah sebagian makna batin dari kewajiban membasuh kaki dalam berwudhu.

\section{KESIMPULAN}

Berdasarkan uraian di atas, maka dapat disimpulkan bahwa thaharah dalam perspektif al-Quran meliputi makna lahir dan makna batin, seperti yang dipahami dari kandungan ayat 4 surah al-Mudatsir. Demikian pula yang dipahami dari kandungan ayat 6 surah al-Maidah, yakni tentang makna batin dari setiap anggota wudhu, baik yang sunah maupun yang wajib menurut syariat dan atau lahirnya di atas. Bertolak dari uraian kedua ayat tersebut, dapat dipahami dan ditegaskan bahwa betapa banyak kaum muslimin yang telah berwudhu secara syariat tapi minus hakekat. Inilah yang menjadi problem fundamental dalam beragama di kalangan umat Islam. Yakni mereka beragama secara lahir namun minus batin. Mereka beragama secara syariat minus hakekat. Mereka dalam beragama berhenti pada syariat agama sebagai sarana, namun tidak sampai pada tujuan beragama. Cara dan metode keberagamaan yang demikian ini, mesti dirubah. Yakni kemestian beragama berdasarkan syariat lahiriah plus makna batin. Bersyariat sekaligus berhakekat. Inilah 
bentuk pengamalan agama yang sejati dan sempurna. Yakni beragama secara benar dan lurus (dinnil qayyim). Setiap ayat al-Quran mesti dipahami berdasarkan logika bayani (tekstual), logika burhani (kontestual) dan sekaligus irfaniy (spiritual).

\section{DAFTAR PUSTAKA}

Al-Quran al-Karim

Ash-Shabuniy. Muhammad Ali, Shafwatut Tafasir. Bairut: Dar al-Fikr, t.th. Al-Baqi. Muhammad Fuad Abdul. Mu'jam Mufakhras li Alfaz al-Quran. Bairut: Dar al-Fikr. T. th.

Al-Damaghaniy. Al-Husain Ibn Muhammad. Qamus al-Quran. Bairut: Daar alAlamiin. T.th.

Al-Ashfaniy, Mufardaat li Alfaz al-Quran. Bairut: Daar al-Syamiyah. T.th.

Ibnu Zakariah. Abi Husain Ahmad Ibnu Faris. Maqaayis al-Lughat. Bairut: Daar al-Fikr. T.th.

Munawwir. Ahmad Warson. Kamus al-Munawwir.

Shihab. Quraish. Tafsir al-Misbah. Jakarta: Lentera Hati. 2001.

Zuhaili. Wahbah. Tafsir al-Munir. Bairut: Dar al-Ilm. T.th. 